\title{
Produkti geoinformacijske podpore planiranju in urejanju prostora v okviru projekta ONIX
}

Prostorsko planiranje

Prostorsko upravljanje Geografski informacijski sistem

Prispevek na kratko opisuje štiri produkte podprojekta Geoinformacijska podpora planiranju in urejanju prostora na ravni lokalne skupnosti $v$ okviru projekta ONIX. Produkti so rezultat celovitega pristopa $k$ razvoju informacijske podpore, ki ga karakterizira enovita obravnava prostorskih aktov od prostorskega plana, izvedbenih aktov do postopkov lokacije, multidisciplinarni pristop in objektno usmerjeni informacijski pristop.

Physical planning Spatial management Geographic information system

The article gives a brief description of four products in the subproject Geoinformation support for physical planning and spatial management on the local level in the framework of the Onix project. The products are a result of a comprehensive approach to the development of information support, whose main features are unified dealing with planning acts, from the statutory plan and development plans to permitting procedures, multi-disciplinary approach and object oriented information approach.

\section{Uvod}

Cilj podprojekta Geoinformacijska podpora planiranju in urejanju prostora na lokalni ravni (GPPP) je krepitev posameznih komponent informacijske podpore planiranju in urejanju prostora na občinski ravni. Rezultati podprojekta so številni: od analiz in ocen stanja, vsebinskih in informacijskih zasnov ter preveritev, podatkovnih in postopkovnih modelov, izobraževalnih aktivnosti do implementacije posameznih podsistemov. $\mathrm{Na}$ tem mestu želimo na kratko predstaviti štiri t.i. "dostavljene" produkte ("deliverables") pilotni Mestni občini Koper:

- NRP - podatkovna baza namenske rabe prostora za celotno območje Mestne občine Koper

- PIA - podatkovna baza izvedbenih aktov Mestne občine Koper

- AUIG - aplikacija urbanistične informacije - grafična sestavina

- AUIA - aplikacija urbanistične informacije - alfanumerična sestavina

Posebno vrednost zgoraj naštetim produktom daje njihova medsebojna integriranost v skupno učinkovito orodje za informiranje in odločanje o možnih posegih v prostor.

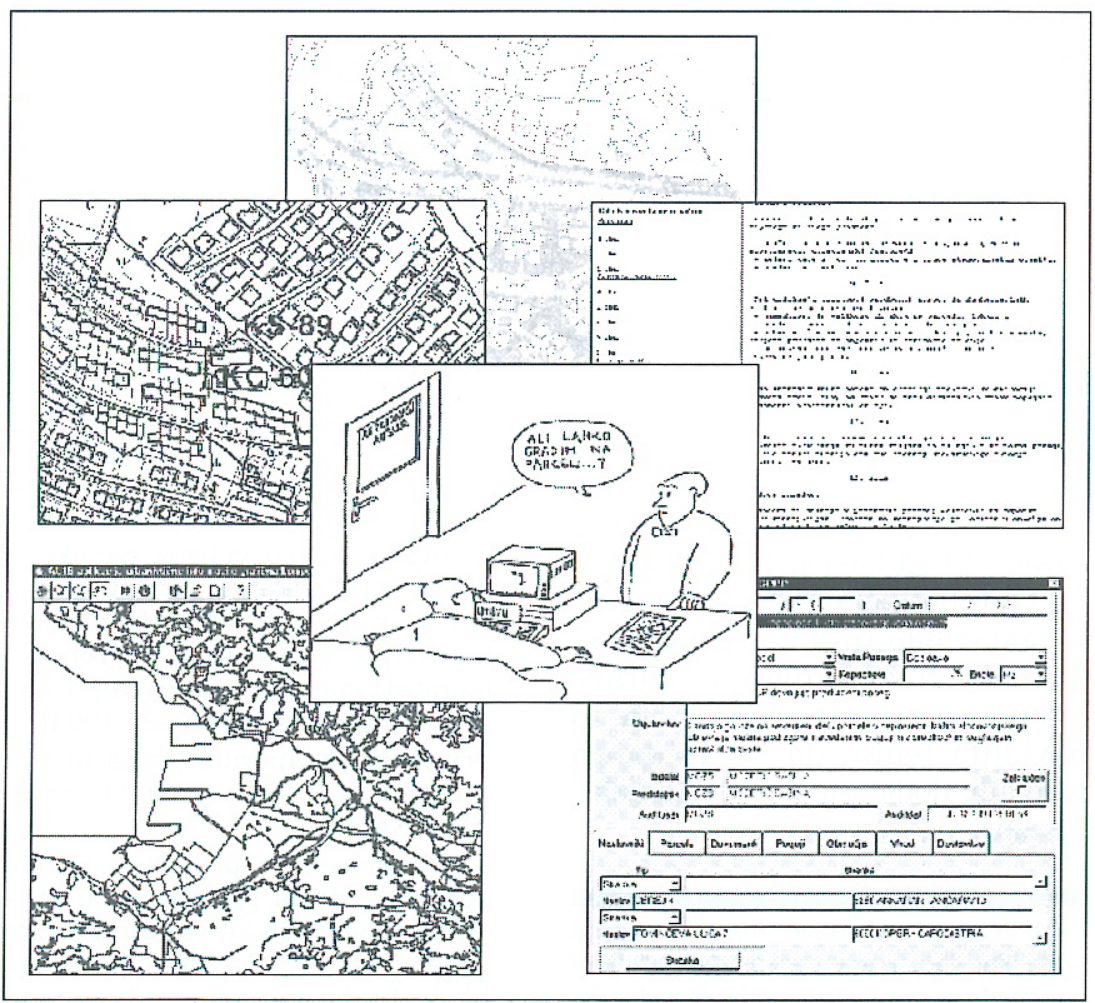

Shema 1: Integriranost produktov geoinformacijske podpore planiranju in urejanju prostora 


\section{Produkt: podatkovna baza namenske rabe za celotno območje Mestne občine Koper}

Produkt je podatkovna baza namenske rabe prostora (NRP) v okviru občinskega prostorskega plana Mestne občine Koper. Glede na potrebe po transparentnem pravnem stanju namenske rabe prostora je bil v okviru GPPP pripravljen nov pristop $\mathrm{k}$ sami vsebinski opredelitvi namenske rabe $\mathrm{v}$ okviru občinskega prostorskega plana. Zato pomenita razvoj in implementacija NRP tudi prototipno testiranje na novo opredeljene vsebine namenske rabe prostora. Osnovna enota podatkovne baze NRP je t.i. območje urejanja, ki je opisano $\mathrm{z}$ geokodami meje in centroida območja, oznako, imenom, površino in kategorijo pretežne namenske rabe prostora. Območja urejanja pokrijejo območje celotne občine (60 TTN5000 kart). Vsebina podatkovne baze je opisana po standardu ISO 10303-11 EXPRESS-G.

Osnovne lastnosti podatkovne baze so naslednje:

- podatkovna baza je čistoris pravnega stanja namenske rabe in predstavlja enotno vsebino urbanistične zasnove in kartografske dokumentacije $\mathrm{Z}$ vsemi spremembami in dopolnitvami vključno s spremembo v postopku za območje krajinskega parka Škocjanski Zatok,

- meje območij urejanja so gekodirane $z$ maksimalno pozicijsko natančnostjo glede na topografijo in digitalne katastrske načrte,

- kategorije namenske rabe so natančno opredeljene in definirane, $z$ opisom katere dejavnosti sodijo, ne sodijo oziroma pogojno sodijo v določeno kategorijo namenske rabe,

- območjem urejanja so določene enolične oznake, ki omogočajo nedvoumno sklicevanje tekstualnih in drugih določb $\mathrm{v}$ okviru prostorskega plana in prostorskih izvedbenih aktov.
Izris iz podatkovne baze NRP je kot sprememba in dopolnitev občinskega plana v postopku sprejema na Mestnem svetu Mestne občine Koper. V ostale občine Republike Slovenije pa priporočamo prenos naslednjih vsebin:

- novo vsebinsko opredelitev namenske rabe prostora,

- načrt in obliko podatkovne baze NRP,

- klasifikacijo namenske rabe prostora,

- navodilo za oznake območij urejanja,

- postopke in izkušnje pri pripravi podatkovne baze, ki so razvidni iz protokolov zajema in so sestavni del dokumentacije produkta.

\section{Produkt: podatkovna baza prostorskih izvedbenih aktov Mestne občine Koper}

Produkt je podatkovna baza celotne pravno veljavne dokumentacije prostorskih izvedbenih aktov (PIA) Mestne občine Koper. Podatkovna baza vsebuje za vsak PIA naslednje sklope podatkov:

- geokodirano mejo območja veljavnosti PIA,

- odlok o PIA.

- celotno tekstualno in grafično dokumentacijo PIA.

Vsebina podatkovne baze, ki zadeva mejo območja veljavnosti PIA, je opisana po standardu ISO 10303-11 EXPRESS-G. Podatkovna baza obsega celotno dokumentacijo 10-ih prostorskih izvedbenih aktov, kar so praktično vsi akti, ki so trenutno $\mathrm{v}$ uporabi v Mestni občini Koper. To pomeni, da je vsa relevantna pravno veljavna dokumentacija, ki zadeva prostorske izvedbene akte, v elektronski obliki.

$\mathrm{Na}$ področju PIA priporočamo v vse občine prenos naslednjih vsebin:

- načrt in oblika podatkovne baze PIA,
- postopki pri pripravi podatkovne baze (procedure, natančnosti, geokodiranje), ki so razvidni iz protokolov zajema in so sestavni del dokumentacije produkta.

\section{Produkt: aplikacija urbanistične informacije - grafiččna sestavina}

Produkt je računalniška aplikacija urbanistične informacije - grafični del (AUIG) za podporo pri izdaji urbanistične informacije in splošno iskanje podatkov o pogojih nameravanega posega $\mathrm{v}$ prostor.

Aplikacija AUIG omogoča:

- iskanje in pregledovanje slojev namenske rabe prostora NRP in prostorskih izvedbenih aktov PIA,

- brskanje po odlokih PIA (ninternet" oblika),

- pregledovanje geokodiranih slojev kartografske dokumentacije PIA,

- pregledovanje grafičnih slojev PIA,

- uporabo slojev podlog: TTN 5000 , Orto 5000 in digitalnih katastrskih načrtov,

- pripravo poročila za urbanistično informacijo,

- direktno povezavo z AUIA - alfanumerično sestavino.

Posebne odlike aplikacije AUIG:

- enostavna ("intuitivna") uporaba aplikacije, ki je primerna ne le za referente, ampak tudi za vodstvene delavce,

- enoten pristop do geokodiranih kart, grafičnih prikazov in tekstnih besedil,

- glede na uporabo sodobnega principa komponentnega razvoja programske opreme so možne relativno enostavne in hitre nadgraditve in razširitve aplikacije.

Aplikacija AUIG je prenosljiva v ostale občine ob ustrezni prilagoditvi predvsem dejanskemu podatkovnemu okolju občine. 


\section{Produkt: aplikacija urbanistične informacije - alfanumerična sestavina}

Produkt je računalniška aplikacija urbanistične informacije - alfanumerčni del (AUIA) za podporo izdaji urbanistične informacije.

Aplikacija AUIA omogoča:

- pregledovanje alfanumeričnih podatkov, relevantnih za urbanistično informacijo (parcele, naslovi, šifranti ...),

- pripravo dokumenta urbanistične informacije $v$ obliki formaliziranega elektronskega obrazca,

- direktno povezavo z AUIG grafično sestavino.

Posebne odlike aplikacije AUIA:

- glede na to, da je aplikacija AUIA integrirana $\mathrm{v}$ informacij- ski sistem pisarniškega poslovanja Mestne občine Koper, referent pri izdelavi urbanistične informacije ostaja $\mathrm{v}$ istem delovnem okolju,

- glede na uporabo orodja za razvoj programske opreme so možne relativno enostavne in hitre nadgraditve in razširitve aplikacije.

Aplikacija AUIA je prenosljiva v ostale občine ob ustrezni prilagoditvi predvsem dejanskemu podatkovnemu in organizacijskemu okolju občine.

\section{Zaključek}

Menimo, da so rezultati podprojekta GPPP v celoti uporabni tudi za vse ostale občine $\mathrm{v}$ Republiki Sloveniji, neodvisno od velikosti občine. Način uporabe rezultatov je odvisen prevsem od stanja na področju planiranja in urejanja

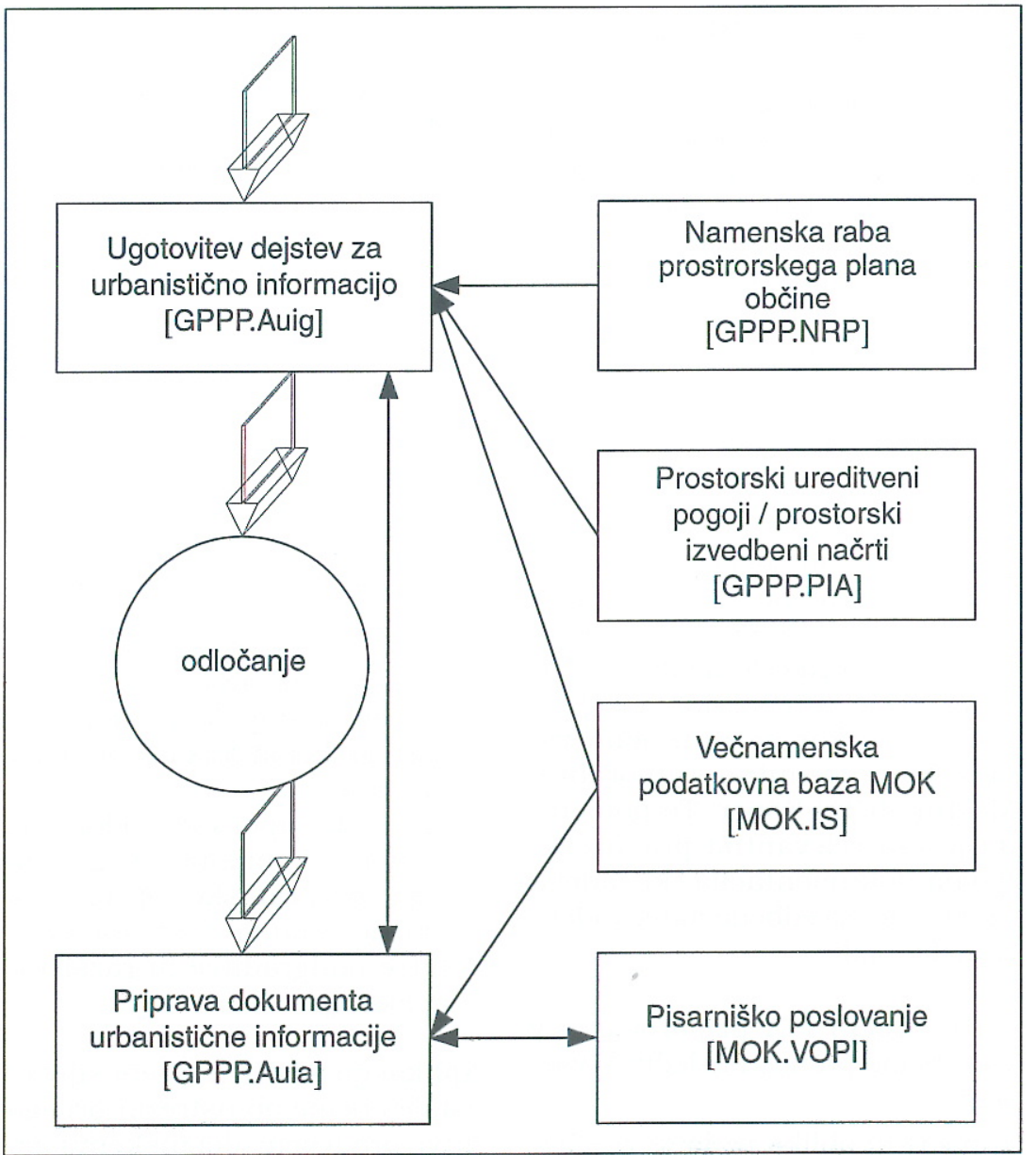

Shema 2: Moduli aplikacije AUI prostora, stanja informacijske podpore in organiziranosti posamezne občine.

Glede na formalnopravni vidik uporabe rezultatov ONIX - GPPP predlagamo:

- takojšen sprejem navodila o vsebini podatkovne baze namenske rabe prostora (vključno s klasifikacijo namenske rabe prostora in navodilom za oznake območij urejanja),

- uveljavljanje rezultatov ONIX GPPP pri pripravi nove prostorske zakonodaje.

Glede na organizacijski vidik uporabe rezultatov ONIX-GPPP predlagamo:

- imenovanje delovne skupine pri Uradu za prostorsko planiranje za svetovanje in nadzor pri pripravi podatkovne baze NRP v posameznih občinah Slovenije,

- oblikovanje enotnega projekta na ravni države za tehnično in finančno pomoč občinam pri uveljavljanju rezultatov ONIXGPPP,

- razširitev rezultatov v sosednje občine.

Franc J. Zakrajšek, univ. dipl. inž. mat., Urbanistični inštitut RS

\section{Pojasnilo}

Avtor članka je vodja izvajalske skupine na podprojektu Geoinformacijska podpora planiranju in urejanju prostora na lokalni ravni $v$ okviru projekta ONIX, katerega naročnik je Ministrstvo za okolje in prostor, Geoinformacijski center, financer pa Svetouna banka.

\section{Viri in literatura}

Urbanistični inštitut Republike Slovenije in dr. GPPP implementacija - zaključno poročilo:

Paket NRP - namenska raba prostora Paket PIA - prostorski izvedbeni akti

Paket AUIG - aplikacija urbanistične informacije - grafična komponenta

Paket AUIA - aplikacija urbanistične informacije - alfanumerična komponenta 